\title{
Possible lava tube system in a hummocky lava flow at Daund, western Deccan Volcanic Province, India
}

\author{
Raymond A Duraiswami ${ }^{1 *}$, Ninad R Bondre ${ }^{2}$ and Gauri Dole ${ }^{1}$ \\ ${ }^{1}$ Department of Geology, University of Pune, Pune 411 007, India. \\ ${ }^{2}$ Department of Geology, Miami University, Oxford, Ohio 45056. \\ *e-mail: raymond_d@rediffmail.com
}

\begin{abstract}
A hummocky flow characterised by the presence of toes, lobes, tumuli and possible lava tube system is exposed near Daund, western Deccan Volcanic Province, India. The lava tube system is exposed as several exhumed outcrops and is composed of complex branching and discontinuous segments. The roof of the lava tube has collapsed but original lava tube walls and fragments of the tube roof are seen at numerous places along the tube. At some places the tube walls exhibit a single layer of lava lining, whereas, at other places it shows an additional layer characterised by smooth surface and polygonal cracks. The presence of a branching and meandering lava tube system in the Daund flow, which represents the terminal parts of Thakurwadi Formation, shows that the hummocky flow developed at a low local volumetric flow rate. This tube system developed in the thinner parts of the flow sequence; and tumuli developed in areas where the tube clogged temporarily in the sluggish flow.
\end{abstract}

\section{Introduction}

The emplacement history of ancient flood basalt lava flows can be deciphered by comparing them with modern flows whose emplacement dynamics are well documented (Duraiswami et al 2003; Solana et al 2004). Lava tubes have been identified both in ancient and modern flows and thus provide an opportunity to understand their genesis and role in the emplacement of these flows. This is especially true considering the fact that tubes are known to provide an insulated and efficient mode of lava transport, thereby influencing the aspect ratio and emplacement dynamics of flows (also see Bondre et al, this issue). In fact, it is believed that most long lava flows that are greater than $100 \mathrm{~km}$ long are essentially tube-fed (Keszthelyi and Self 1998).

In the western parts of the Deccan Volcanic Province (DVP) a number of structures have been identified as lava tubes/channels in the last decade (Thorat 1996; Sharma and Vaddadi 1996). Misra (2002a) has described the tubes in relation to the regional setup, although a few structures identified by him as tubes/channels are probably cryptic lava flows (see Dole et al 2002, Duraiswami et al, in press). A review of existing literature reveals incomplete understanding of the exact nature of these structures i.e., they have been vaguely described as lava tubes/channels. Relationships of tubes to flow lobes, tumuli and sheets have not been described in detail and geochemical and petrographic characters of tubes and associated flows are by and large lacking (except Chatterjee 2001). Moreover, models of tube formation in relation to flow emplacement and implications of such features to emplacement dynamics of flows have also not been attempted. The present paper attempts to address some of the above mentioned aspects in the light of the presence of a possible lava tube within the Daund flow. 


\section{Geology around Daund}

Five lava flows are exposed in the Daund area, approximately $300 \mathrm{~km}$ southeast of Mumbai (figure 1). The lowermost flow (F1), designated here as the Daund flow is exposed as discontinuous outcrops along the course of the Bhima river. It consists of lower hummocky units (described in detail in the later section) and an upper sheet lobe with a basal crust characterised by the presence of pipe vesicles and a core with numerous vesicle cylinders. The contact between F1 and F2 is concealed beneath alluvium, but wherever exposed the contact appears to be sharp and is devoid of any inter flow bole. Flow F2 is 'simple' (sensu Bondre et al 2004) and is separated from flow F3 by $0.70 \mathrm{~m}$ thick red bole. At places, the bole is green in colour. The flow F3 is compound and consists of lower hummocky flow units and an upper sheet lobe similar to flow F1. The hummocky part of the flow is characterised by lava toes, P-type (pipe bearing) lobes (Wilmoth and Walker 1993), lava inflation clefts and lava fingers. The upper sheet lobe is $13.34 \mathrm{~m}$ thick. It consists of a $0.26 \mathrm{~m}$ thick pipe vesicle bearing basal crust, thick $(10.38 \mathrm{~m})$ jointed core and $2.70 \mathrm{~m}$ thick upper vesicular crust. Flow 'F3' is separated by flow F4 by $0.40 \mathrm{~m}$ thick red bole horizon. Flow F4 is a thick simple flow with a dense, massive and highly jointed core. The upper crust of this flow contains large, irregular megavesicles and cavities with silica lining. A $2.5 \mathrm{~m}$ thick flow top breccia separates flow F4 from flow F5. Flow F5 is also simple and characterized by a highly jointed core and partly exposed crust with large rounded to sub-rounded vesicles. Sheet jointing and bouldery outcrops characterize the upper surface of the flow.

Using field characters Godbole et al (1996) and Geological Survey of India (1998) have classified the flow sequence of Daund area into Upper Ratangarh, Indrayani, Karla and Purandargarh Formations. On the other hand, Khadri et al (1999) using geochemical characters divided the flow sequence into Thakurwadi, Bhimashankar, Khandala, Poladpur and Ambenali Formations. Thus, five flows in Daund-Kurkumbh area are unique as they represent extremely thin terminal portions of older parts of western Deccan sequence that shows overstepping by the initial thin parts of younger sequence.

\subsection{The Daund flow (F1)}

This flow belongs to the Thakurwadi Formation and is characterized by the presence of toes, lobes and tumuli observed in scattered outcrops (Duraiswami et al 2001). The flow is fine grained, plagioclase-phyric, and has numerous spherical vesicles that are filled with zeolites. The presence of lobes and tumuli gives a hummocky appearance to the flow, especially in the upper parts where several lobes and toes (see figure 2 of Duraiswami et al 2001 and figure 7c of Bondre et al 2004) are exposed. The crust of a thick lobe is exposed at the base of a section cut by the river along the southern bank near Daund. The upper parts of crust contain small inflation clefts that are occupied by small bulbous squeeze-ups. There are several scattered outcrops near the Railway Bridge across the Bhima river. Several large tumuli and a system of tube-like structures are exposed in these outcrops. The lobes and tumuli are of various shapes and sizes, with lengths ranging from 2.80 to $35.10 \mathrm{~m}$ and widths from 3.21 to $22.32 \mathrm{~m}$ (Duraiswami et al 2002). Most of these have upper surfaces that are festooned by large-amplitude ropes indicative of movement of the lava beneath the viscoelastic crust (Fink and Fletcher 1978).

The outcrops near Sonwadi are typically of hummocky pahoehoe and contain several large lobes and tumuli. In one of the outcrop, a $21.4 \mathrm{~m}$ long slender tumulus is exposed. The medial squeezeup exposed at the tip of this tumulus has given rise to another $3.45 \mathrm{~m}$ long flow-lobe tumulus and a prominent outflow. The outflow is $3.36 \mathrm{~m}$ long, $1.50 \mathrm{~m}$ wide, and $0.50 \mathrm{~m}$ thick and its surface contains large amplitude ropes. The outcrops are also made up of several sheet lobes with large inflation clefts that are occupied by thick (up to $0.70 \mathrm{~m}$ ) squeeze-ups. The squeeze-ups are highly vesicular and contain phenocrysts $(\sim 0.5$ to $1 \mathrm{~cm}$ ) of plagioclase. These plagioclase pheoncrysts are larger than those in the flow and tend to concentrate towards the centre of the squeeze-ups.

Petrographically, the Daund flow consists of microphenocrysts $(\sim 5 \mathrm{~mm})$ of plagioclase and iddingsite pseudomorphs after olivine in a finegrained groundmass of plagioclase, clinopyroxene, glass and opaques. The plagioclase microphenocrysts are compositionally zoned and inclusions are present along the zonning planes. These plagioclase microphenocrysts along with the iddingsite pseudomorphs often cluster to display the characteristic glomeroporphyritic texture. The squeeze-ups from the Daund flow show similar petrography except that their modal plagioclase content is higher than that of the host (table 1).

\subsection{The lava tube}

A possible tube like structure is exposed in scattered outcrops near the Railway Bridge across Bhima river. The structure is curvilinear (figure 2) and has undergone considerable erosion. It is preserved as a shallow empty, non-roofed depression flanked by tube walls. The roof of the tube appears 

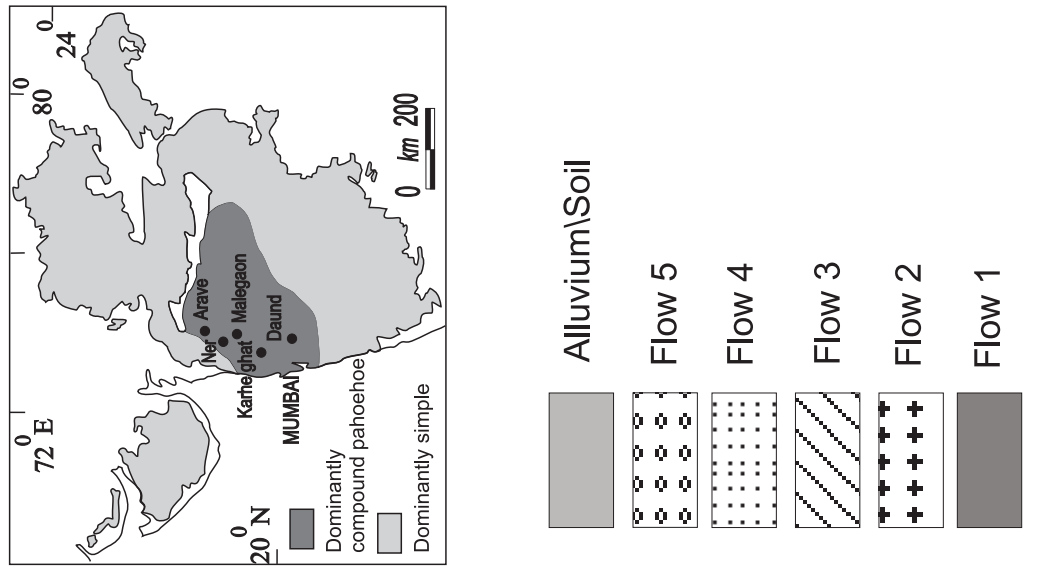

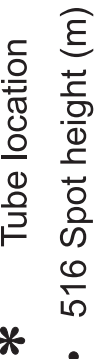

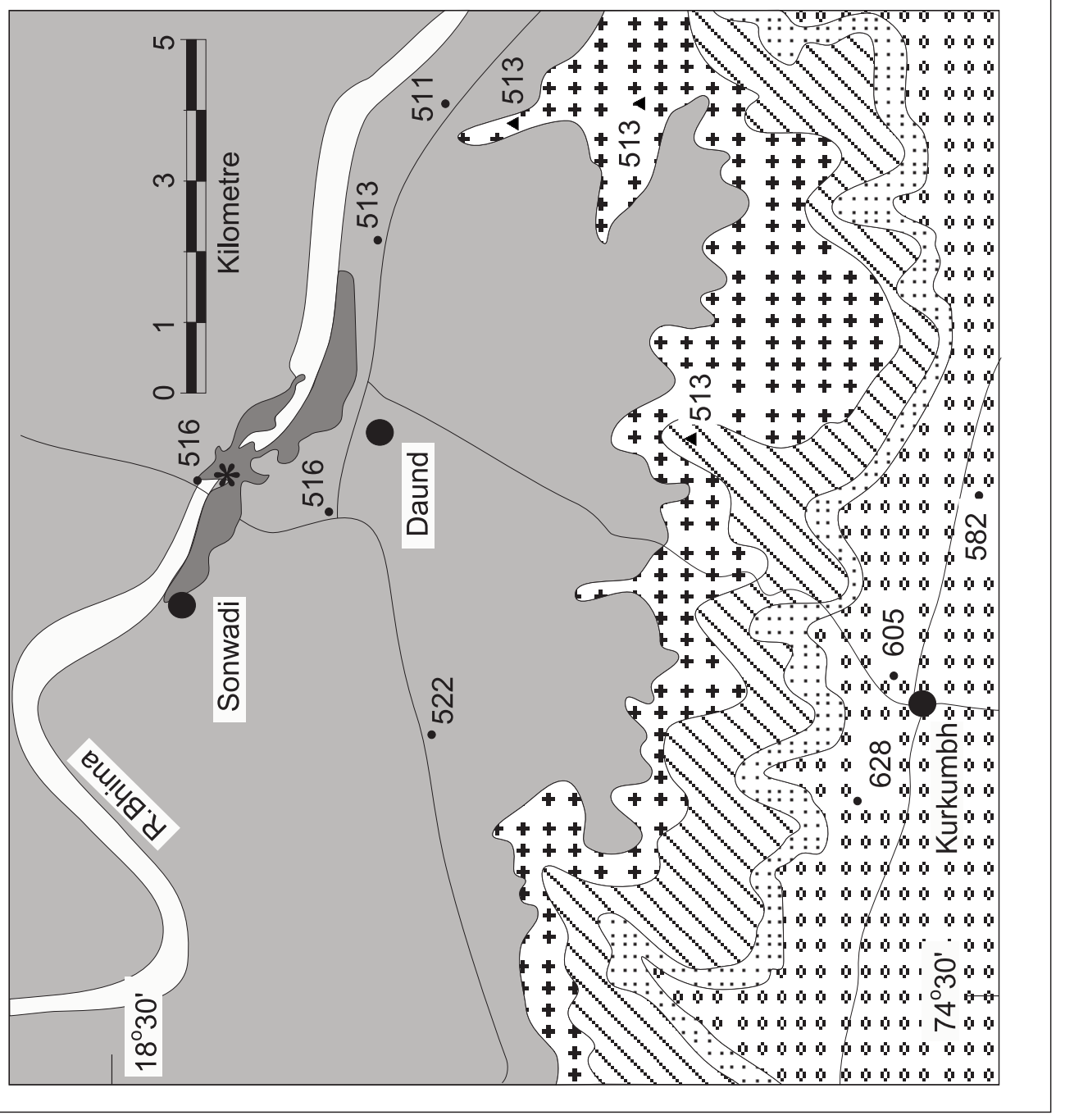

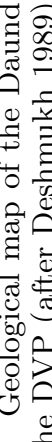

$-\frac{9}{\square}$

ㅇ. ㅋ.

$\underbrace{}_{0} 0$ 
Table 1. Major oxide (wt.\%) and trace element (ppm) concentrations and mineral modes (\%) of samples from the Daund flow.

\begin{tabular}{|c|c|c|c|c|c|}
\hline & \multicolumn{2}{|c|}{ Daund tube } & \multicolumn{3}{|c|}{ Daund flow } \\
\hline & Inner lining & Outer lining & Basalt 1 & Basalt 2 & Squeeze-up \\
\hline$\overline{\mathrm{SiO}_{2}}$ & 49.12 & 49.45 & 49.69 & 49.42 & 49.00 \\
\hline $\mathrm{Al}_{2} \mathrm{O}_{3}$ & 13.89 & 13.73 & 13.43 & 12.85 & 15.30 \\
\hline $\mathrm{TiO}_{2}$ & 2.05 & 2.1 & 2.17 & 2.16 & 1.84 \\
\hline $\mathrm{FeO}^{\mathrm{T}}$ & 14.15 & 14.52 & 14.88 & 14.78 & 12.80 \\
\hline $\mathrm{MnO}$ & 0.15 & 0.19 & 0.18 & 0.2 & 0.20 \\
\hline $\mathrm{CaO}$ & 8.98 & 9.18 & 9.33 & 9.47 & 9.42 \\
\hline $\mathrm{MgO}$ & 4.44 & 4.64 & 4.92 & 4.99 & 4.54 \\
\hline $\mathrm{K}_{2} \mathrm{O}$ & 1.77 & 0.93 & 0.86 & 1.11 & 0.59 \\
\hline $\mathrm{Na}_{2} \mathrm{O}$ & 2.41 & 2.42 & 2.35 & 2.21 & 2.29 \\
\hline $\mathrm{P}_{2} \mathrm{O}_{5}$ & 0.22 & 0.22 & 0.23 & 0.25 & 0.19 \\
\hline Total & 97.18 & 97.38 & 98.04 & 97.44 & 96.17 \\
\hline \multicolumn{6}{|c|}{ Trace elements } \\
\hline $\mathrm{Ba}$ & 195 & 226 & 200 & 173 & 103 \\
\hline $\mathrm{Cr}$ & 38 & 39 & 37 & 38 & 52 \\
\hline $\mathrm{Cu}$ & 137 & 141 & 149 & 144 & 136 \\
\hline $\mathrm{Ni}$ & 37 & 41 & 38 & 40 & 33 \\
\hline $\mathrm{Rb}$ & 71 & 23 & 13 & 30 & 10 \\
\hline $\mathrm{Sc}$ & 31 & 33 & 37 & 34 & 30 \\
\hline $\mathrm{Sr}$ & 248 & 259 & 257 & 226 & 232 \\
\hline $\mathrm{V}$ & 308 & 312 & 289 & 325 & 320 \\
\hline $\mathrm{Y}$ & 30 & 34 & 33 & 34 & 34 \\
\hline $\mathrm{Zn}$ & 100 & 107 & 108 & 111 & 115 \\
\hline $\mathrm{Zr}$ & 179 & 181 & 186 & 181 & 155 \\
\hline $\mathrm{Nb}$ & 11 & 12 & 12 & 12 & 10 \\
\hline Co & 43 & 43 & 51 & 50 & 42 \\
\hline \multicolumn{6}{|c|}{ Modal abundance } \\
\hline Plagioclase $(p)$ & 2 & 5 & 8 & 12 & 14 \\
\hline Plagioclase $(g)$ & 29 & 35 & 27 & 30 & 28 \\
\hline Clinopyroxene & 46 & 19 & 13 & 24 & 31 \\
\hline Olivine & 0 & 1 & 5 & 1 & 1 \\
\hline Opagues & 6 & 12 & 11 & 2 & 3 \\
\hline Glass & 19 & 29 & 35 & 32 & 23 \\
\hline
\end{tabular}

to have collapsed/eroded. Segments that constitute the structure generally trend in the $\mathrm{N} 60^{\circ}-240^{\circ}$ direction. The main segment of the tube can be traced for about $100 \mathrm{~m}$ in a single outcrop (figure 2). However, the cumulative length of such segments from various outcrops is more than $300 \mathrm{~m}$. The northern wall of the tube shows variable dips between $9^{\circ}$ and $22^{\circ}$ (figure $3 \mathrm{a}$ ). This wall appears to show two distinct layers, each with different vesicle content, jointing pattern, and petrography. The inner layer displays large, circular vesicles, with a high vesicle density. This layer has a regular polygonal jointing pattern. In contrast, the outer layer is characterized by joints that are perpendicular to the trend of the tube. This layer has smaller vesicles and has a low vesicle density. The average width of the tube floor varies from $5.53 \mathrm{~m}$ towards the western end to $1.70 \mathrm{~m}$ in the east. The floor of the tube is almost horizontal. Towards the southeastern wall of the main tube floor, a $0.30 \mathrm{~m}$ wide and $0.40 \mathrm{~m}$ deep structure is encountered. We term this depression as a 'lava gutter', which is filled partly by a fine-grained, leucocratic, clay-like material (figure $2 \mathrm{~b}$ ). The walls of the lava gutter exhibit variable dips.

An $\sim 3.5 \mathrm{~m}$ high outcrop adjacent to the tube near the road bridge across the Bhima river at Daund distinctly establishes the relationship of the tube to the flow units. The wall of the tube is exposed for $0.50 \mathrm{~m}$ in this section and is overlain by a $0.90 \mathrm{~m}$ thick, reddish brown vesicular basalt. The vesicles of the basalt are extremely fine and 


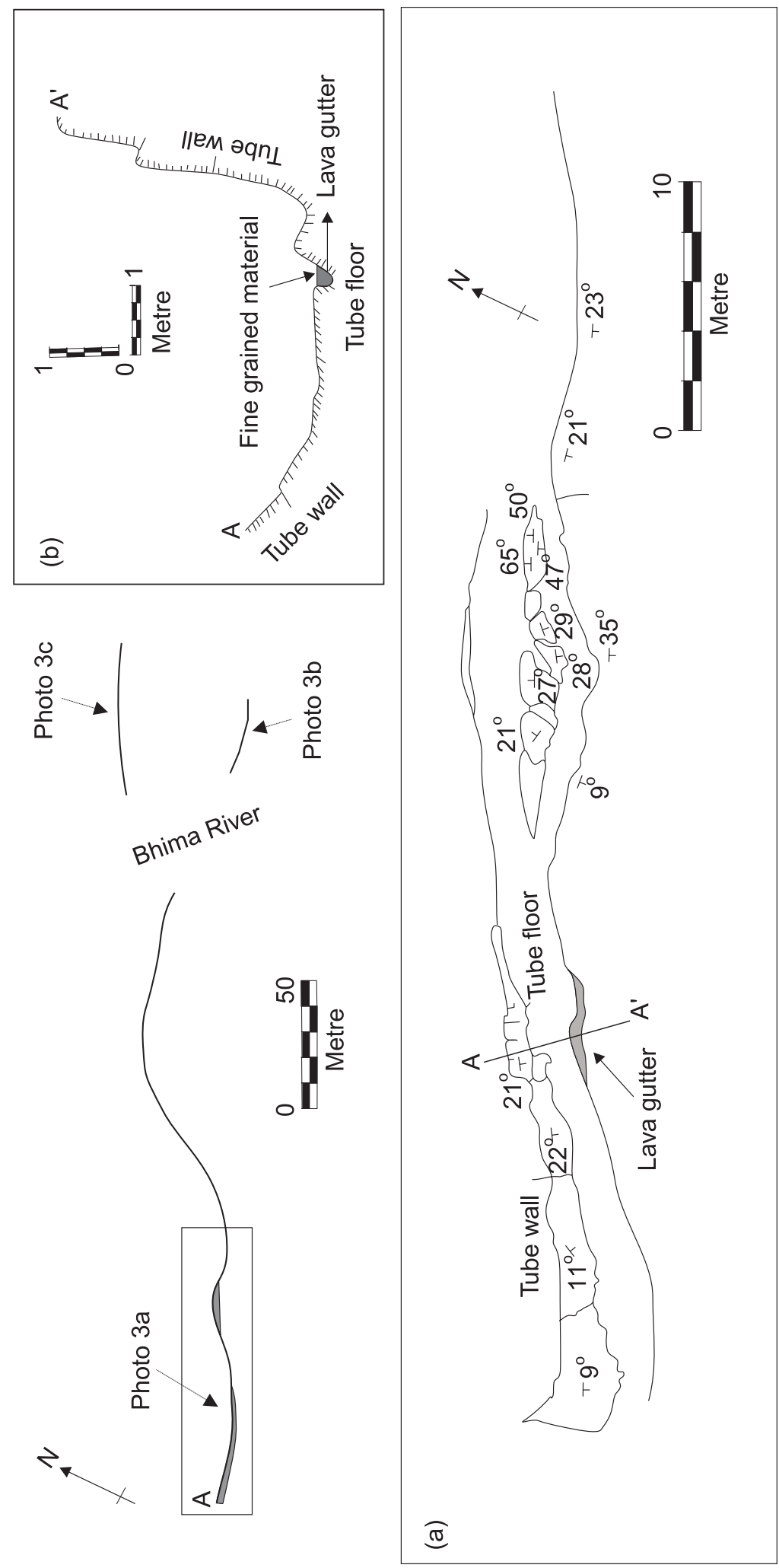

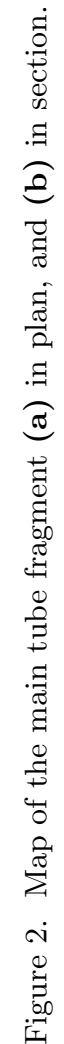




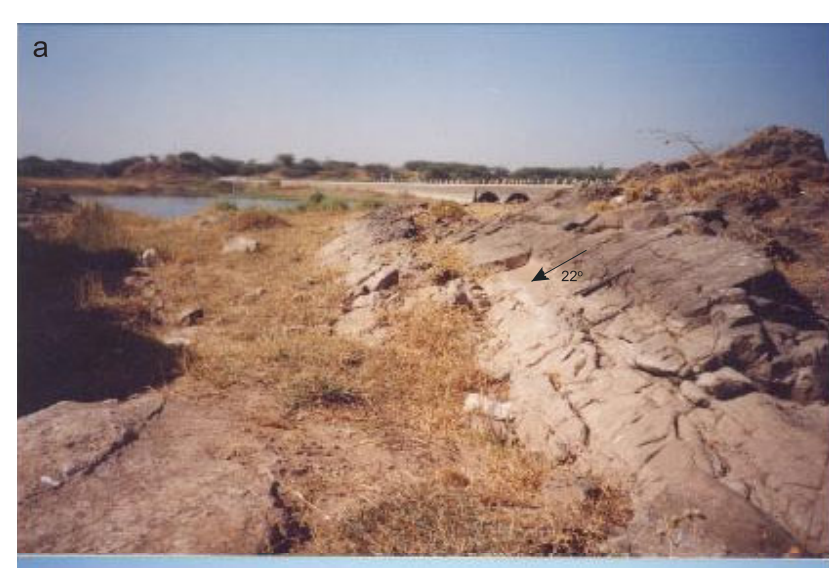

b

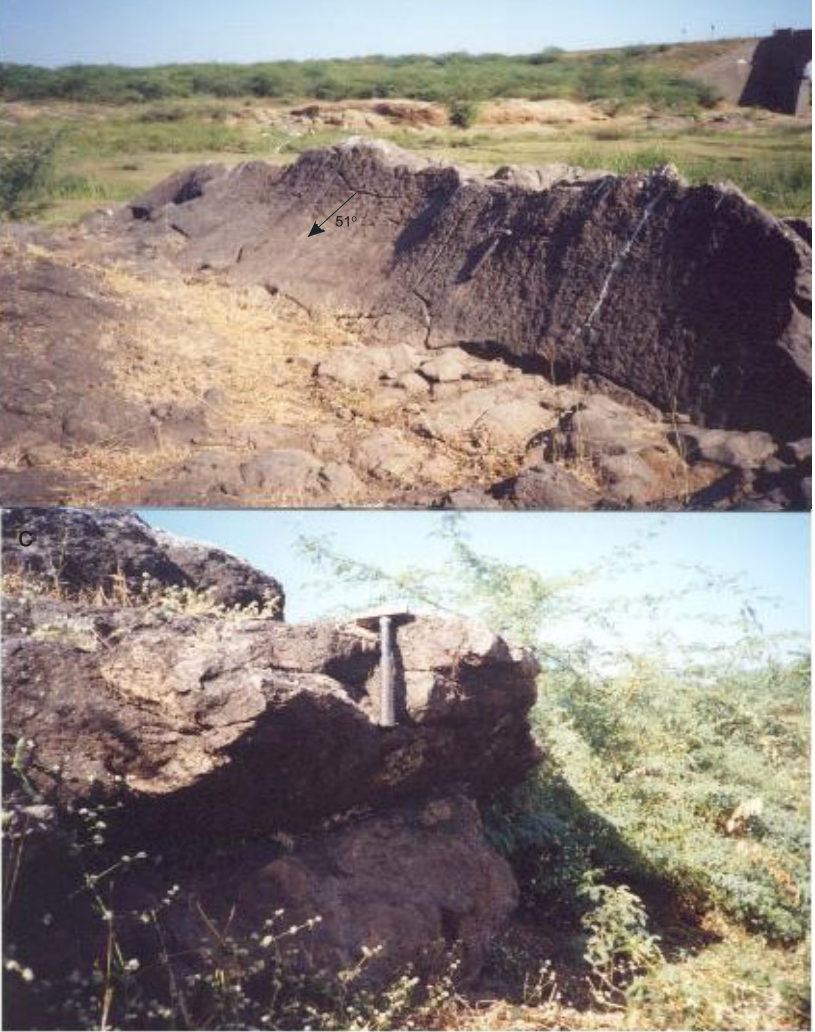

Figure 3. Field photographs (a) Fragment of the northwestern tube wall, (b) part of the southeastern wall exhibiting steep dips, and (c) fragment of the roof of the lava tube.

are invariably filled by zeolite minerals. The surface of this unit is exposed at places and is marked by large patches of zeolite mineralisation and thin layer of crypto-crystalline silica. The upper surface of this unit dips by $23^{\circ}$ to the southeast. An $\sim 0.42 \mathrm{~m}$ thick unit overlies the vesicular basalt and consists of distinct P-type pahoehoe. The lengths of the lobes vary from 0.65 to $2.81 \mathrm{~m}$. The uppermost unit is a highly vesicular, pinkish, plagioclase phyric basalt. The vesicles are larger than those found in the lower basalts and are invariably filled by zeolites. A $0.45 \mathrm{~m}$ thick squeeze-up intrudes through this basalt. The disposition of the pahoehoe lobes vis-à-vis the axis of the tube is such that the long axis of the lobes appear to dip away from the axis of the tube. It is therefore concluded that the tube provided elevated regions over which the overlying lobes were emplaced. A couple of branches of the tube system are also exposed on the northern bank of the Bhima river. The northeastern branch is discontinuously exposed and only the fragments of the eastern wall are present (figure $3 \mathrm{~b}$ ). Similar features depicted in figure 3(a) and $3(\mathrm{~b})$ resemble those of tube segments on the 1736 Montana de las Nueces flow field, Lanzorote, Canary Islands (Solana et al 2004). The segments of the tube wall show high dips $\left(30^{\circ}\right.$ to $\left.60^{\circ}\right)$. The surface of the tube wall is very smooth and appears glazed, with distinct cracks. The glaze is the result of sustained high temperature (L Keszthelyi, Pers. Comm., 2004). A segment of the northwestern branch can also be traced for more than $50 \mathrm{~m}$ and occurs as a sinuous depression (up to $\sim 1.5 \mathrm{~m}$ wide). This depression is complete with lava walls and at places, fragments that could be part of the tube roof (figure 3c). Alternatively, these fragments may also represent tumulus crust, roofed over the tube.

The petrography of the tube wall layers also provides interesting insights into the cooling history of the lava tube. The outermost layer of the tube has a slightly fine texture than the inner layer and is characterized by high modal plagioclase, opaques and glass (table 1). The inner layer, in contrast, has high modal clinopyroxene. Moreover, olivine is seen only in the samples from the outer tube layer. This indicates that the inner tube was better insulated and maintained a higher temperature than the outer parts of the tube.

\section{Geochemistry}

Four representative samples, including two from the tube and two samples from the flow, were analysed for major and selected trace elements by X-ray fluorescence (XRF) technique at the Earthquake Research Centre, Japan. Similarly, geochemical composition of one squeeze-up was analysed by the Direct Current Plasma Atomic Emission Spectrometery (DCP-AES) at the Department of Geology, Miami University, Ohio. The analyses of the samples are presented in table 1 . The trace and rare earth elements of the sample from the Daund flow are presented in table 2. Samples from a flow exposed in the Karheghat section belonging to the Thakurwadi Formation (Khadri et al 1989) were also analysed and are produced in table 2 for the sake of comparison. The primitive mantle (Hofmann 1998) normalized plots shows compositional similarity between the present data set and 
Table 2. Select trace element and Rare Earth Element (ppm) concentrations from the Daund flow in comparison with the samples (Kr2h and Kr1s) from a flow exposed in Karheghat section near Sangamner belonging to Thakurwadi Formation.

\begin{tabular}{|c|c|c|c|}
\hline \multirow{2}{*}{\multicolumn{2}{|c|}{$\begin{array}{c}\text { Daund flow } \\
\text { DDF1 }\end{array}$}} & \multicolumn{2}{|c|}{ Kareghat flow } \\
\hline & & $\mathrm{Kr} 2 \mathrm{~h}$ & Kr1s \\
\hline $\mathrm{Rb}$ & 10 & 9.6 & 20 \\
\hline $\mathrm{Ba}$ & 103 & 130 & 172 \\
\hline $\mathrm{Th}$ & 3.7 & 2.8 & 5 \\
\hline $\mathrm{Nb}$ & 10 & 7 & 13 \\
\hline $\mathrm{U}$ & 0.84 & 0.62 & 1.1 \\
\hline $\mathrm{La}$ & 19 & 15 & 25 \\
\hline $\mathrm{Ce}$ & 40 & 32 & 55 \\
\hline $\operatorname{Pr}$ & 5.2 & 4.2 & 7.2 \\
\hline $\mathrm{Pb}$ & 5 & 3 & 6 \\
\hline $\mathrm{Sr}$ & 232 & 324 & 309 \\
\hline $\mathrm{Nd}$ & 23 & 18 & 32 \\
\hline $\mathrm{Zr}$ & 155 & 124 & 212 \\
\hline $\mathrm{Hf}$ & 4.2 & 3.2 & 5.6 \\
\hline $\mathrm{Sm}$ & 5.7 & 4.5 & 7.7 \\
\hline $\mathrm{Eu}$ & 2 & 1.5 & 2.3 \\
\hline $\mathrm{Gd}$ & 6.5 & 5 & 8.6 \\
\hline Dy & 6 & 4.4 & 7.5 \\
\hline Ho & 1.2 & 0.88 & 1.5 \\
\hline $\mathrm{Y}$ & 34 & 26 & 42 \\
\hline Er & 3.1 & 2.3 & 3.7 \\
\hline $\mathrm{Tm}$ & 0.46 & 0.1 & 0.55 \\
\hline $\mathrm{Yb}$ & 2.7 & 1.9 & 3.2 \\
\hline $\mathrm{Lu}$ & 0.42 & 0.3 & 0.5 \\
\hline $\mathrm{Ga}$ & 23 & 19 & 20 \\
\hline $\mathrm{Sc}$ & 30 & 32 & 31 \\
\hline $\mathrm{V}$ & 320 & 249 & 349 \\
\hline $\mathrm{Co}$ & 42 & 45 & 46 \\
\hline $\mathrm{Ni}$ & 33 & 75 & 33 \\
\hline $\mathrm{Cu}$ & 136 & 139 & 222 \\
\hline $\mathrm{Zn}$ & 115 & 98 & 141 \\
\hline $\mathrm{Cr}$ & 52 & 242 & 11 \\
\hline
\end{tabular}

that of flows belonging to the Thakurwadi Formation (figure 4) thereby supporting the field classification of flows.

There appears to be a good similarity between the major and trace element concentration of the samples from the tube and the basaltic flow. However, within the tube samples, subtle differences between the inner and outer lining of the tube vis-à-vis the flow provides interesting insights into the cooling histories and emplacement of the tubefed hummocky flows. The inner layer of the tube is depleted in silica, total iron, calcium, magnesium, and enriched in alumina in comparison to the outer layer. Modal analysis of various mineral phases also reflects such subtle variations (table 1). The possibility that the chemistry of the magma varied subtly over the emplacement duration and is responsible for the variations cannot be discounted. However, given that the geochemical variation within the tube-lining falls within the analytical error, further detailed geochemical investigations are necessary for confirmation.

\section{Emplacement mechanism}

It is envisaged that the Daund flow emerged from a vent (from a yet unknown location) and advanced by repeated budding of pahoehoe toes and lobes (see figure 5). Continuous supply of hot, molten lava within a viscoelastic crust induced inflation and some lobes grew steadily into sheet lobes wherever the gradient was gentle. However, where the gradient was steeper, preferred pathways gradually developed. Lava tubes formed along the most rapidly flowing part of the active lava flow. The tubes in the present case appear to have formed in the terminal parts and along the flow margins as in the case of lava tubes in Cave Basalt, Mount St. Helens (Greeley and Hyde 1972). Configuration of the pre-flow surface influenced the overall trend of the lava tubes and meandering of the flow indicates either lava fluidity or an irregular microtopography (Greeley and Hyde 1972). The axis of the tube i.e., tube roof probably formed a topographic swell with the slope away and perpendicular to the axis (Greeley 1971). The flow lobes and tumuli exposed near the tubes developed into elongated forms with their longer axis perpendicular to the tube axis. Such associations between tumuli and tubes have been found on flows from Mount St. Helens (Greeley and Hyde 1972), Etna (Guest et al 1984) and Hawaii (Mattox et al 1993; Hon et al 1994). In the advanced stage of development, the flow spread laterally and the main tube supplied lava to the flow front through distributory feeder tubes (Greeley and Hyde 1972), especially in the thinner parts of the flow (Greeley 1971). The distributory tubes often got plugged, bifurcated repeatedly and some formed cut-off branches. The flow-lobe tumuli developed at the terminal ends of the flow and at places where the tube clogged temporally in the sluggish flow (Duraiswami et al 2002). Although this may be true in the case of the Daund flow, it is not necessary that tumuli form at the end of tubes or due to cloggages (Hon et al 1994). During tube drainage or lava withdrawal, a layer of fresh lava accreted along the walls of the tube. The lava gutter may owe its development to slight scouring of the tube floor during a focused/channeled movement of lava. The sinuous depressions observed in the Daund flow were probably formed by drain out (withdrawal) of molten 


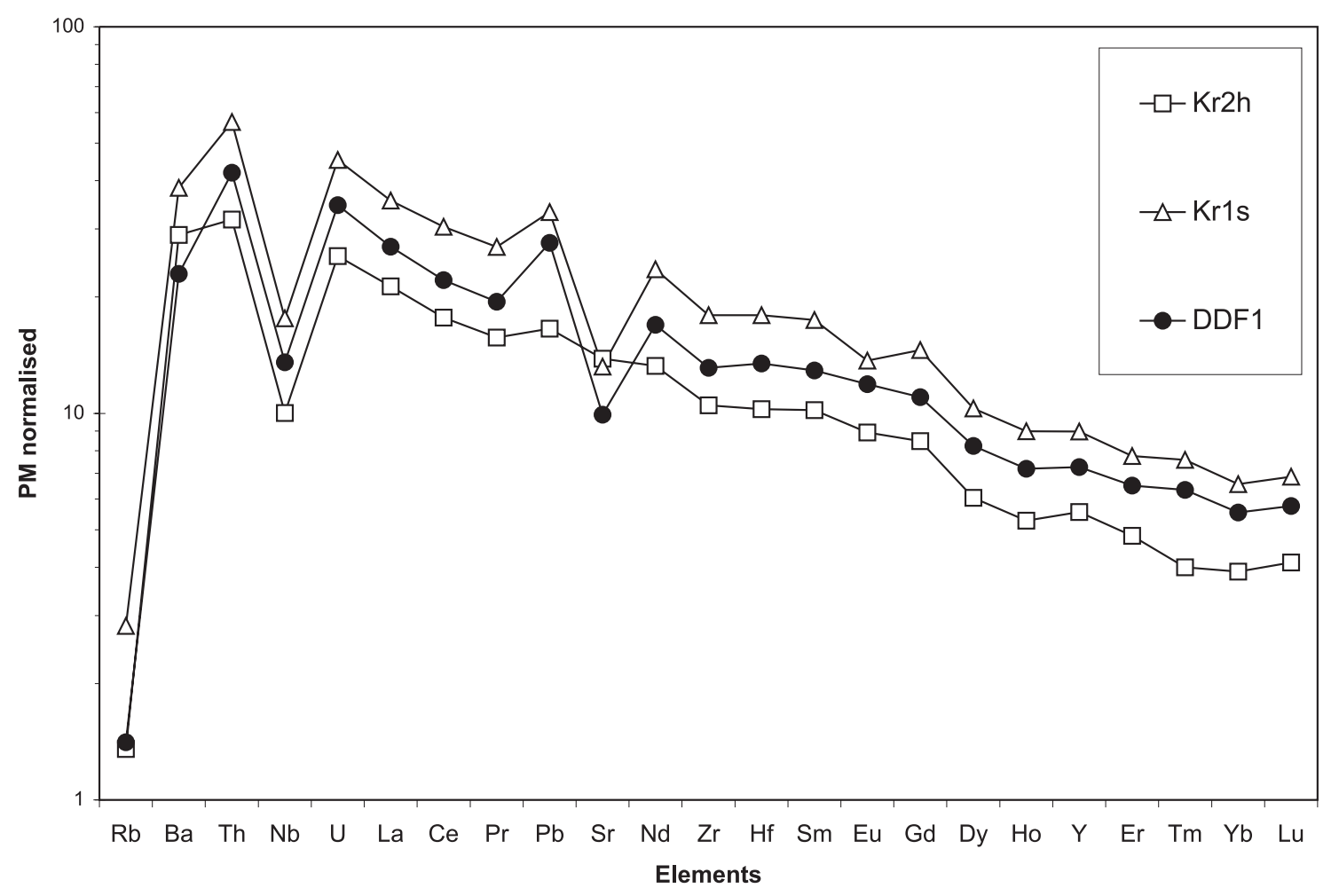

Figure 4. Primitive mantle normalized Rare Earth Element concentration of the Daund flow.

lava from tubes beneath the partly cooled thin surface crust (Greeley 1971). Alternatively, the rupturing of the roof of the tube by the weight of the overlying flow was responsible for the formation of the depressions. Subsequently, the river exhumed the sinuous depressions of the tube and the upper parts of the flow surface, which are now preserved as the Daund flow.

\section{Discussion}

Dimensions of terrestrial lava tubes may be up to $15 \mathrm{~m}$ in diameter and $20 \mathrm{~km}$ long, but most are less than $10 \mathrm{~m}$ wide and $1-2 \mathrm{~km}$ long (Horz 1985). Lava tubes from Hawaii are known to extend for kilometers with widths from 1 to $8 \mathrm{~m}$ (Peterson and Swanson 1974). The Wahaula tube, Kilauea has presumably a total length of $1100 \mathrm{~m}$ and width of up to $5 \mathrm{~m}$ (Keszthelyi 1995). Measured cave tubes, such as the Silver Cave and the Arch Cave from Mammoth Crater, Medicine Lake Highlands, U.S.A. have lengths of $600 \mathrm{~m}$ and $100 \mathrm{~m}$ and widths of $6 \mathrm{~m}$ and $10 \mathrm{~m}$ respectively (Halliday 1962; Waters et al 1990). The Boyd Cave tube of the Horse lava tube system, Bend, Oregon has a length of $568 \mathrm{~m}$ and maximum width of $9.7 \mathrm{~m}$ (Greeley 1971). Similarly, the ABC Cave tube, Chyulu Hills, Kenya, has a length of $1000 \mathrm{~m}$ with a maximum width of $9 \mathrm{~m}$ (Simons 1998). The tube segments from the Daund flow measure to an aggregate length of about $300 \mathrm{~m}$, although the original length of tube may have been longer. The dimension of the tube from the Daund flow therefore compares well with most small features from other provinces. This has two implications, either (1) the tube in question is preserved in part, or (2) is a branch of a major undiscovered and/or un-preserved tube.

The presence of segments of a lava tube within a hummocky lava flow, complete with the presence of toes, lobes and sheets lends a unique opportunity to model the emplacement of ancient hummocky flows. Segments of channels/tubes have been reported from all over the western DVP (see Thorat 1996; Sharma and Vaddadi 1996; Misra et al 2001, Misra 2002a) and most of these are restricted to the known occurrences of hummocky pahoehoe flows (e.g., near Ner, Arave, Mukti, Malegaon, etc.) Hummocky pahoehoe are generally considered to be tube fed and are known to develop when the effusion rates are low and the micro topography is irregular (Swanson 1973). This indicates that at least the local transport of lava in the Deccan may have been affected by tubes. Hummocky pahoehoe flows are also known from other parts of the DVP i.e., from Saurashtra, Malwa and Amarkantak areas. Reports of occurrences of tubes from these parts are however rare (Thorat 2001) and may be attributed to the lack of concerted efforts in identification of such structures rather 


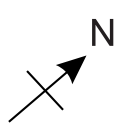

In plan

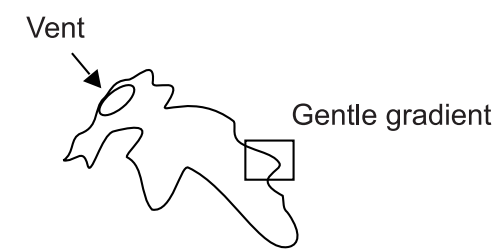

Development of flow field
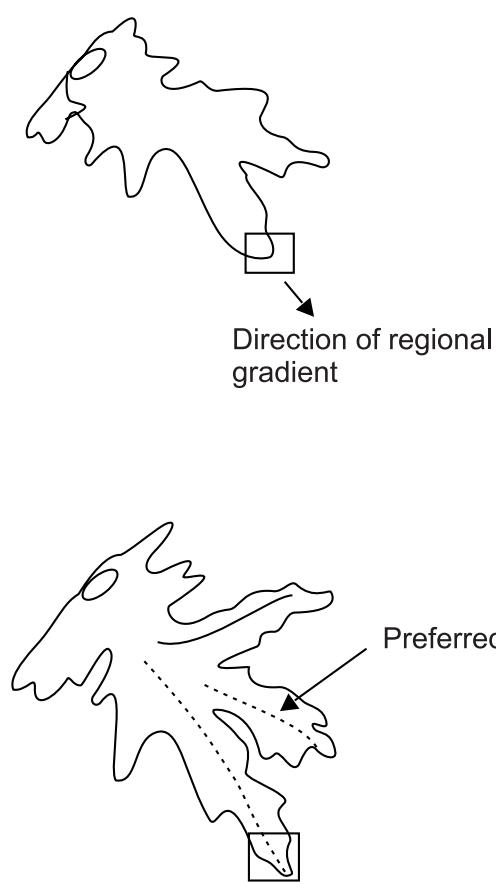

\section{Preferred pathway}

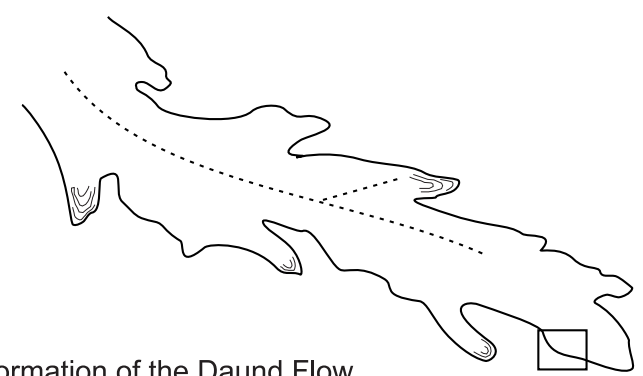

\section{In section}
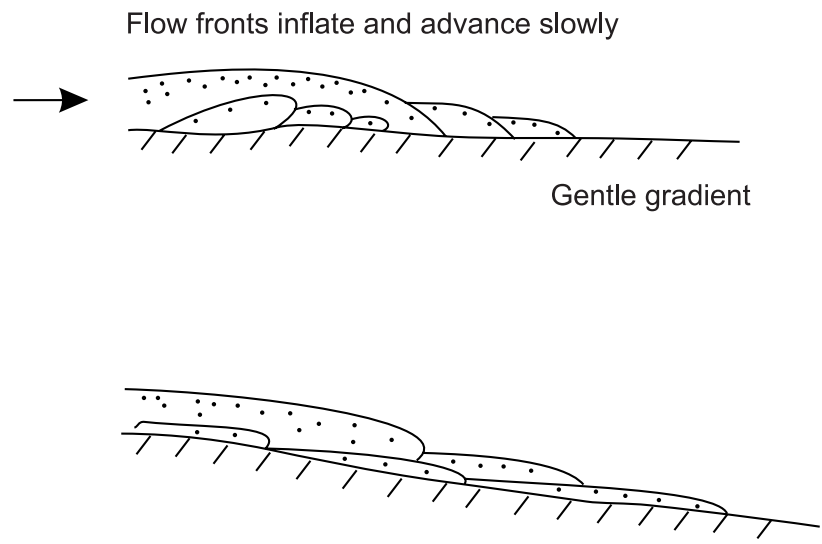

Steeper gradient
Formation of tubes as preferred pathways along the higher gradient

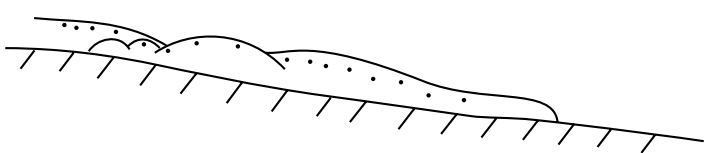

Steeper gradient

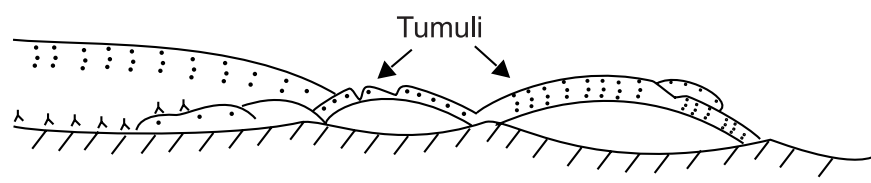

Irregular micro-topography

Figure 5. Schematic diagram depicting the emplacement of the hummocky flow at Daund and the formation of tubes and tumuli.

than their absence. Indeed if remnants of tubes are present in significant numbers in these regions, then their nature and orientation might shed light on the emplacement mechanism of the flows in these regions. In more than one aspect, their presence may eventually help in building a better eruptive model for the DVP. The exhumation levels in the DVP are such that they provide a unique opportunity to explore various emplacement models in time and space, and to evaluate the role of lava tubes in building large CFB provinces. This will have far reaching consequences in the development of emplacement models for terrestrial and extra-terrestrial volcanic fields. 
Very high effusion rates are believed to be responsible for the formation of certain tubular structures having large dimensions and evidences of thermal erosion at the base of lava tubes/channels is recorded in the proximity of effusive centers (Misra 2002b). The presence of hummocky flows in almost all of the geographical domains of the DVP indicates that the flows may have been emplaced at relatively low local effusion rates (Duraiswami et al 2001) and evidence such as mechanical erosion of the substrate or incorporation of foreign material within the flows indicative of turbulent emplacement of flows is generally lacking in the DVP (Chatterjee et al 2001).

\section{Conclusions}

The presence of tube-like structures as an efficient mode of lava transfer, particularly in case of the Daund flow was envisaged by Duraiswami et al (2001) on the basis of presence and alignment of tumuli. Detailed mapping of the flow has revealed the presence of tube segments within the flow, thereby confirming its tube fed nature. The mechanism of tube formation in the Daund flow was controlled by low effusion rate, gradient (ground slope) and microtopography. The tubes fed the lava flow that propagated by repeated branching of toes and lobes and grew endogenously. Although the number of tube segments from the Daund flow may be far too few, it is almost certain that numerous other structures (preferred pathways) were active at the same time around the presently exposed structure. The present morphology of the structure is entirely related to the process of differential erosion and exhumation. Thus, tube-fed pahoehoe did exist during the Deccan volcanism, at least on a local scale. Only more detailed mapping in other parts of the Deccan will shed light on whether tubes were long enough, and thermally efficient enough to transport large volumes of lava over long distances.

\section{Acknowledgements}

RAD dedicates this paper to his departed cousin Renald Michael Joseph. The authors are indebted to Prof. Ichiro Kaneoka, Earthquake Research Center, Japan for the XRF analysis. The authors are thankful for the comments of the reviewers, Dr. Lazlo Keszthelyi, United States Geological Survey and Dr. Stephen Self, The Open University, U.K. that helped in improving the quality of the paper. We thank Dr. Hetu Sheth for inviting us to contribute to this special volume and for his constructive suggestions regarding the contents of this paper. Dr. Makarand Bodas, Geological Survey of India has been ever so helpful with his views and suggestions. His comments helped to improve the quality of this paper by many folds. Discussions with Dr. N R Karmalkar and Dr. Vivek Kale were illuminating and thought provoking.

\section{References}

Bondre N R, Duraiswami R A and Dole G 2004 Morphology and emplacement of flows from the Deccan Volcanic Province, India; Bull. Volcanol. 66 29-45

Chatterjee A K 2001 Petrography and petrochemistry of the lava tubes in Gunjale and Mulanagar sectors, Ahmednagar District, Maharashtra; Geol. Surv. India Spl. Pub. 64 511-528

Chatterjee K K, Gupta A and Deshmukh S S 2001 A theoretical approach to emplacement mechanism of Deccan Flood Basalt; Geol. Surv. India Spl. Pub. 64 529-541

Deshmukh S S 1989 Petrographic variations in compound flows in Deccan Traps and their significance. Mem. Geol. Soc. India 10 305-319

Dole G, Bondre N R, Duraiswami R A and Kale V S 2002 Discussion on: Arterial system of lava tubes and channels within Deccan Volcanics of Western India by K S Misra; J. Geol. Soc. India 60 597-600

Duraiswami R A, Bondre N R, Dole G, Phadnis V M and Kale V S 2001 Tumuli and associated features from the western Deccan Volcanic Province, India; Bull. Volcanol. $63435-442$

Duraiswami R A, Bondre N R, Dole G and Phadnis V M 2002 Morphology and structure of flow-lobe tumuli from the western Deccan Volcanic Province, India; J. Geol. Soc. India 60 57-65

Duraiswami R A, Dole G and Bondre N R 2003 Slabby pahoehoe from the western Deccan Volcanic Province: evidence for incipient pahoehoe-aa transitions; J. Volcanol. Geotherm. Res. 121 195-217

Duraiswami R A, Dole G and Bondre N R The Songir structure: inflated lava flow or tube? J. Geol. Soc. India, Bangalore (in press)

Fink J H and Fletcher R C 1978 Ropy pahoehoe: surface folding of a viscous fluid; J. Volcanol. Geotherm. Res. 5 $151-170$

Geological Survey of India 1998 Quadrangle Geological Map of Baramati Quadrangle (Government of India Press)

Godbole S M, Rana R S and Natu S R 1996 Lava stratigraphy of Deccan basalts of western Maharashtra; Gond. Geol. Mag. Spl. Publ. 2 125-134

Greeley R 1971 Geology of the selected lava tubes in the Bend area, Oregon; Bull. 71, Dept. Geol. Min. Ind, Oregon

Greeley R and Hyde J H 1972 Lava tubes of Cave Basalt, Mount St. Helens, Washington; Geol. Soc. Am. Bull. 83 2397-2418

Guest J E, Wood C and Greeley R 1984 Lava tubes, terraces and megatumuli on the 1614-24 pahoehoe lava flow field, Mount Etna; Geol. Mag. 17 601-606

Halliday W R 1962 Caves of California; 193 pp.

Hofmann A W 1998 Chemical differentiation of the Earth: relationship between mantle, continental crust and oceanic crust; Earth Planet. Sci. Lett. 90 297-314

Hon K, Kauahikaua J, Denlinger R and MacKay K 1994 Emplacement and inflation of pahoehoe sheet flows: observations and measurements of active lava flows on Kilauea Volcano, Hawaii; Geol. Soc. Am. Bull. 106 $351-370$ 
Horz F 1985 Lava tubes: potential shelters for habitats; In: Lunar bases and space activities of the $21^{\text {st }}$ Century (ed) W W Mendell, Huston, Texas, Lunar and Planetary Institute, 405-412

Keszthelyi L 1995 A preliminary thermal budget for lava tubes on the Earth and planets; J. Geophys. Res. 100 20411-20420

Keszthelyi L and Self S 1998 Some physical requirements for the emplacement of long basaltic lava flows; $J \mathrm{Geo-}$ phys. Res. 103 27447-27464

Khadri S R F, Subbarao K V, Hooper P R and Walsh J N 1989 Stratigraphy of Thakurwadi Formation, Western Deccan Basalt Province, India; Mem. Geol. Soc. India 10 281-304

Khadri S R F, Subbarao K V and Walsh J N 1999 Stratigraphy, form and structure of the east Pune basalts, western Deccan Basalt Province, India; Mem. Geol. Soc. India 43 172-202

Mattox T N, Heliker C, Kauahikaua J and Hon K 1993 Development of the 1990 Kalapana flow field, Kilauea volcano, Hawaii; Bull. Volcanol. 55 407-413

Misra K S 2002a Arterial system of lava tubes and channels within Deccan volcanics of western India; J. Geol. Soc. India 59 115-124

Misra K S 2002b Discussion on: Arterial system of lava tubes and channels within Deccan Volcanics of Western India by K S Misra; J. Geol. Soc. India 60 $597-600$

Misra K S, Sabale A B and Bhutani R 2001 Lava channels/tube network in western Maharashtra: study of their morphology, formation and transportation of Deccan lava; Geol. Surv. India Spl. Pub. 64 503-510

Peterson D W and Swanson D A 1974 Observed formation of lava tubes during 1970-71 at Kilauea Volcano, Hawaii; Studies in Speleology 2 209-223

Sharma R K and Vaddadi S 1996 Report on lava tubes/channels from Deccan Volcanic Province; Gond. Geol. Mag. Spl. 2 457-460

Simons J W 1998 Volcanic caves of Kenya, a guide; $8^{\text {th }}$ Int'l. Symposium, Vulcanospeleology. 37pp.

Solana M C, Kilburn C R J, Badiola E R and Aparicio A 2004 Fast emplacement of extensive pahoehoe flow-fields: the case of the 1736 flows from Montana de las Nueces, Lanzarote; J. Volcanol. Geotherm. Res. 132 189-207

Swanson D A 1973 Pahoehoe flows from the 1969-1971 Mauna Ulu eruption, Kilauea Volcano, Hawaii; Geol. Soc. Am. Bull. 84 615-626

Thorat P K 1996 Occurrence of lava channels and tubes in the western part of Deccan Volcanic Province; Gond. Geol. Mag. Spl. Pub. 2 449-456

Thorat P K 2001 Lava channel from the Malwa traps; News Geol. Surv. India, Central Region 1822

Waters A C, Donnelly-Nolan J M and Rogers B W 1990 Selected caves and lava-tube systems in and near Lava Beds National Monument, California; USGS Bulletin 1673

Wilmoth R A and Walker G P L 1993 P-type and S-type pahoehoe: a study of vesicle distribution patterns in Hawaiian lava flows; J. Volcanol. Geotherm. Res. 55 129-142 